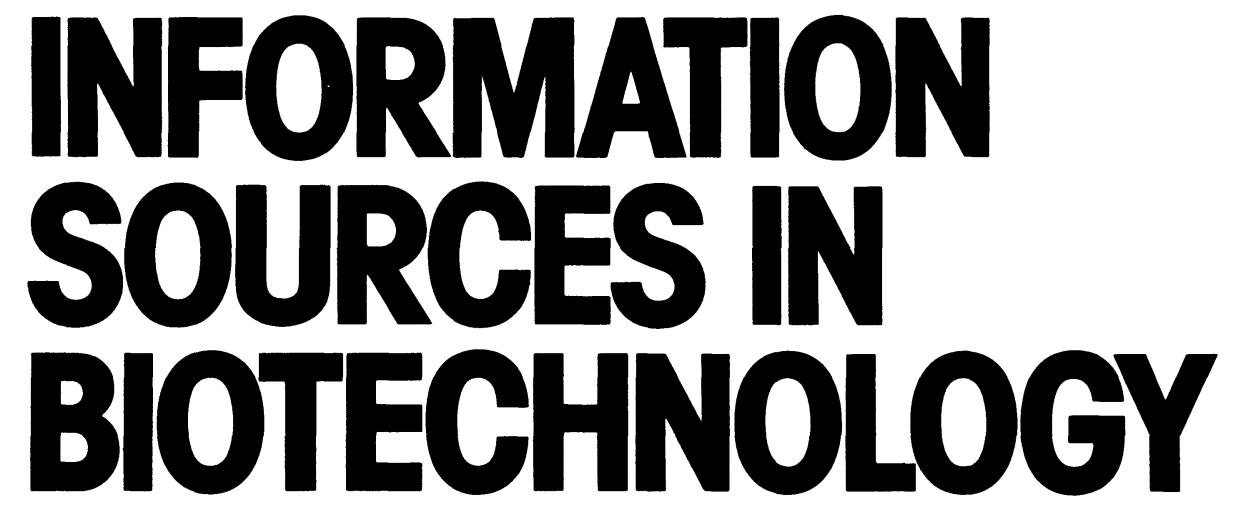

Second Edition

A.Crafts-Lighty

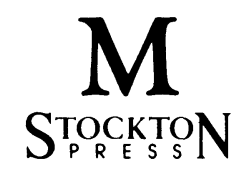


c Macmillan Publishers Ltd, 1986

All rights reserved. No part of this publication may be reproduced, or transmitted, in any form or by any means, without permission.

Published in the United States and Canada by STOCKTON PRESS, 1986

15 East 26th Street, New York, N.Y. 10010

The Library of Congress has catalogued this serial publication as follows:

Library of Congress Cataloguing in Publication Data

Crafts-Lighty, A. (Anita), 1954-

Information sources in biotechnology.

1. Biochemical engineering -- Information services.

I. Title.

TP248.3.C72 $1983 \quad 660^{\prime} .6 \quad 83-17479$

ISBN $978-1-349-08016-8 \quad$ ISBN $978-1-349-08014-4$ (eBook)

DOI $10.1007 / 978-1-349-08014-4$

First published in the United Kingdom by

MACMILLAN PUBLISHERS LTD (Journals Division), 1986

Distributed by Globe Book Services Ltd

Brunel Road, Houndmills, Basingstoke, Hants RG21 2XS, England

British Library Cataloguing in Publication Data

Crafts-Lighty, A.

Information sources in biotechnology, ---2nd ed.

1. Biotechnology---Information services

2. Biotechnology---Bibliography

I. Title

$660^{\prime} .6^{\prime} 07 \quad$ TP248.2

ISSN $0267-4998$ 


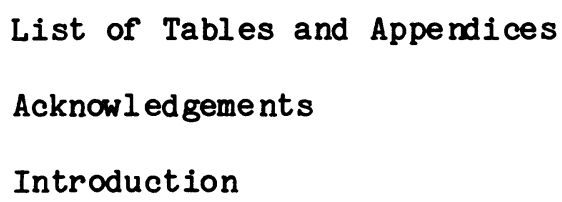

1. What is Biotechnology? The Science and the Business 1 Defining Biotechnology

Basic Biological Principles 3

Genetic Engineering 5

$\begin{array}{ll}\text { Cell Fusion } & 7\end{array}$

$\begin{array}{ll}\text { Cell Culture } & 8\end{array}$

Immobilization 9

Industrial Applications 9

Heal th-Care 9

$\begin{array}{lr}\text { Agriculture } & 12\end{array}$

$\begin{array}{ll}\text { Food Technology } & 13\end{array}$

$\begin{array}{ll}\text { Chemicals } & 14\end{array}$

$\begin{array}{ll}\text { Pollution Control } & 15\end{array}$

$\begin{array}{ll}\text { Other Industrial Processes } & 16\end{array}$

The Structure of the Biotechnology Business 16

2. Information Sources in Biotechnology 24

$\begin{array}{ll}\text { Types of Information Sources } & 24\end{array}$

$\begin{array}{ll}\text { Books } & 25\end{array}$

$\begin{array}{ll}\text { Audio Visual Media } & 25\end{array}$

$\begin{array}{ll}\text { Conferences } & 26\end{array}$

$\begin{array}{ll}\text { Periodicals } & 26\end{array}$

Trade Information $\quad 27$

Secondary Sources $\quad 28$ 
2. Information Sources in Biotechnology (continued)

$\begin{array}{lr}\text { Organizations } & 28\end{array}$

$\begin{array}{ll}\text { Selecting Sources for Purchase } & 28\end{array}$

Using Information Sources for Specific Purposes 30

3. Monographs, Book Series and Textbooks 33

Monographs $\quad 34$

Book Series $\quad 34$

Textbooks, State of the Art Information and Introductory Books 36

4. Conferences and Their Proceedings 94

Conference Proceedings $\quad 94$

$\begin{array}{ll}\text { Published Proceedings } & 95\end{array}$

For thcoming Conferences 96

$\begin{array}{ll}\text { Secondary Sources } & 97\end{array}$

Conference Attendance and Alerting 97

5. Trade Periodicals and Newsletters 129

$\begin{array}{lr}\text { Biotechnology Newsletters } & 129\end{array}$

Other Newsletters 132

$\begin{array}{ll}\text { Newspapers } & 133\end{array}$

6. Research and Review Periodicals 155

$\begin{array}{ll}\text { Review Periodicals } & 155\end{array}$

$\begin{array}{ll}\text { Research Periodicals } & 156\end{array}$

$\begin{array}{ll}\text { Obtaining Research Papers } & 158\end{array}$

$\begin{array}{ll}\text { 7. Abstracting and Secondary Sources } & 198\end{array}$

$\begin{array}{ll}\text { Title Lists } & 198\end{array}$

General Abstracts Journals 199

Biotechnology Abstracts Journals 200

$\begin{array}{ll}\text { Press Cutting Services } & 204\end{array}$

$\begin{array}{lr}\text { Bibliographies } & 204\end{array}$ 
8. Computer Databases 222

Accessing Online Services 222

Equipment $\quad 223$

Tel ecommunications Networks 223

$\begin{array}{ll}\text { Online Hosts } & 224\end{array}$

Getting Online $\quad 225$

Biotechnology Databases $\quad 226$

Other Helpful Databases $\quad 228$

Patent Databases $\quad 230$

Sequence Databanks $\quad 231$

Culture Collections 232

9. Patents and Patenting 265

Patent Applications and Families $\quad 265$

Books on Patenting in Biotechnology 267

Biotechnology Patent Analyses and Bibliographies 269

Newsletters Covering Patents $\quad 271$

Other Sources of Patent Information $\quad 272$

$\begin{array}{ll}\text { Supply of Patents } & 273\end{array}$

Further Reading $\quad 273$

10. Market surveys 289

Selecting and Obtaining Market Surveys 290

Biotechnology Market Surveys 292

Other Information on Market Research 292 
11. Directories of Companies, Products and Research

Biotechnology Company Directories

Out of Print Biotechnology Directories

Other Relevant Company Directories

Product Directories

Biotechnology Research Project Directories

Other Research Directories

12. Organizations

National Governments

International Organizations

Trade Associations

Scientific Societies

Culture Collections

13. Providing Library and Information Services in Biotechnology

Budgets

Functional Integration

Hiring Good People

Flexibility

Service 


\section{List of Tables and Appendices}

Tables

Table 4-1

Table 4-2

Table 5-1

Table 5-2

Table 6-1

Table 6-2

Table 6-3

Table 7-1

Table 7-2

Table 7-3

Table 8-1

Table 8-2

Table 9-1

Table 11-1

Table 11-2

Table 11-3

Table 11-4

Table 11-5

Table 12-1

Table 12-2

Table 12-3

Table 12-4
Major Scientific Societies and Trade Associations Which 98 Organise Biotechnology Conferences and Their Newsletters Research Periodicals Listing Forthcoming Conferences

Biotechnology Newsletters

Other Useful New Periodicals

Annual Reviews, Advances and Book Series Useful for Biotechnology

Other Review Series Useful for Biotechnology

Research Periodicals Containing Biotechnology Articles

General Scientific Title Lists Useful for Biotechnology General Scientific Abstracts Journals Useful for Biotechnology Special ist Biotechnology Abstracts Journals

Specialist Biotechnology Databases

Other Useful Databases for Biotechnology

Patent Coverage of Biotechnology New sletters

Specialist Biotechnology Company Directories 321

Other Useful Commercial Directories

Product and Substance Directories 336

Biotechnology Research Project Directories 342

Research Institute Directories $\quad 345$

Government Agencies in the UK and USA with Activities in 358

Biotechnology

International Organizations with Activities in Biotechnology 361

Scientific Societies in the UK and USA and Multi-Society 363

Organizations with Interests in Biotechnology

Major Culture Collections

\section{Appendices}

Appendix 1-1 Reading List - Introductory Books, Pamphlets and Reviews

Appendix 2-2

Videos and Films on Biotechnology

Appendix 3-1

Reading List - Monographs, Textbooks and Book Series in

Appendix 3-2 Biote chnology

Monographs, Textbooks and Book Series Related to

Appendix 4-1

Proceedings of Biotechnology Conferences

Appendix 7-

Bibliographies in Biotechnology 
Appendix 9-1 Patent Deposit Libraries in Western Europe, UK, USA

Appendix 9-2

Appendix 9-3 and Japan

Official Patent Journals

280

Appendix 9-4

Patent offices

Reading List - Patents and Patenting

282

Appendix 10-1 Market Surveys in Biotechnology

285

Appendix 10-2 Reading List - Market Research

Appendix 13-1 Reading List - Information Management 
Ackorlegenents

I would like to thank the following people whose help and advice has been an important ingredient in the production of this book: Celltech Ltd, the British Library and the Gothard House Group who provided reference material, Lyn Beynon who typed this second edition and my husband Mark Mills. 


\section{Introduction}

The purpose of this book is to describe the information sources which are available in the field of biotechnology. Biotechnology is a multi-disciplinary applied science and an exciting new field of endeavour. It has captured the imagination of both business and the general public and as a result, has received substantial attention in the press over the last ten years. The governments of most developed countries have allocated large sums of money to support research and industrial development in biotechnology and over 500 specialist biotechnology companies have been formed world-wide, many of whom have made very successful public share offerings. As a result of all this, the proliferation of articles, books, journals, patents and newsletters about biotechnology has been nothing short of staggering. Most people have, probably, heard of biotechnology by now, but few seem to know how to find out more about it. As the manager of information services for Celltech, the UK's major specialist biotechnology company from 1981-1985, I receive many letters and telephone calls from students, teachers, researchers, business executives and librarians asking for advice and assistance in finding information about biotechnology and clearly finding it hard to know where to start. This book is for all those people and all the others who have been struggling valiantly alone or contacting my colleagues around the world.

In mid 1983, when the first edition of this book was written, biotechnology was definitely an 'in' subject; a buzzword even, increasingly used to create a high technology image by companies and universities in the hope of attracting attention and money. By early 1986, the glamour has worn off only a little and though the vogue among publishers for anything biotechnological has diminished some what, the flood of new information is still considerable.

One aspect of biotechnology, genetic engineering, is still a topic of considerable public interest and debate because of the long-term possibilities it offers to alter and improve the genetic heritage of agricultural plants, farm animals and even human beings. This potential raises a number of important moral, ethical and ecological questions as well as posing a formidable scientific challenge but there is much more to biotechnology than genetic engineering and much genetic engineering is only concerned with the manipulation of bacteria and yeasts, not 
higher organisms. Biotechnology can, with some difficulty, be defined and treated as a single subject area, albeit one with very fuzzy edges! At least ten different definitions have been published in the last two years, each differing slightly in scope but all encompassing a wide range of industrial processes using biological sy stems and methods.

In this book, those information sources which are clearly concerned with modern biotechnology (as defined in Chapter 1) will be covered in the most detail. However, in many sections it has also been possible to mention some peripheral material which relate to specific applications for biotechnology and to more traditional biotechnological processes as well as some guides to particular types of information sources. The choice of which of these sources to include was of ten difficult, since no work on biotechnology in its broadest sense can be totally comprehensive and remain a readable, managable size. Three further constraints were also placed on the coverage of this book. Only English language publications have been included, no works announced after March 1986 are reviewed and with the exception of a few special review issues mentioned in Appendix 201, individual journal articles are not listed.

Chapter 1 briefly describes the science and business of biotechnology. This is intended as a first introduction to the subject for those who have little or no knowledge of it. Chapter 2 is an overview outlining the types of information sources available in biotechnology. Chapters 3 to 12 discuss particular categories of sources in detail and review the most important ones in some depth. Chapter 13 discusses library management of biotechnology material and the provision of information services in biotechnology. In each chapter, the aim is to provide brief critical reviews of the most important information sources, together with bibliographic details of many others. A final appendix contains a complete list of the addresses of all the publishers mentioned in this book. Additional appendices at the end of some chapters give lists of publications for further reading and other information. For the readers' ease, the tables have been placed at the end of each chapter just before the appendices.

It is inevitable that a few information sources will have been omitted and, as time goes on, of course, many new works will appear. In the appendices of this second edition, new or substantially altered entries are indicated with an asterisk so that new material may be spotted easily. It is hoped that a third edition of this book may be produced and, therefore, the author would be grateful to be notified of any omissions which readers may detect. All views expressed in this work are these personal opinions of the author and do not constitute any endorsement or otherwise of any cited source by the author's previous employers, Celltech Ltd or the author's company BioCommerce Data Ltd and no liability is accepted for any errors or omissions. 